\title{
MOTIVATION INCREASING TO STUDY FOREIGN LANGUAGES FOR MASTER STUDENTS OF ENGINEERING EDUCATION
}

\author{
Elena Zlobina \\ Vyatka State University, Russia \\ alyona.zlobina@gmail.com
}

\begin{abstract}
The aim of the research is to find new methods how to increase motivation to study foreign languages in the sphere of engineering education for specific purposes. One of such methods is foreign language contest. The article represents techniques of developing tasks for organization of foreign language contest to increase motivation to study foreign languages. The main scientific method is questionnaire. The aim of the first questionnaire was to determine, if there was wish or unwillingness of students to take part in the foreign language activities organized by the university, and also to find out, if applicants for the Master degree of engineering education needed the knowledge of foreign languages for the professional purposes. Having got data of the first questionnaire the contest in foreign languages for applicants of the Master degree was organized and held in the university. Having held the contest, the second questionnaire was organized and it gave positive changes in the motivation to study foreign languages. Participants of the organized foreign language contest were applicants for the Master degree from different universities of the Russian Federation representing the following engineering education: chemical engineering, civil engineering, mechanical engineering, electrical engineering. As a result, this research shows the possibilities of motivation increasing to study foreign languages at applicants for the Master degree of engineering education by organizing foreign language activities.
\end{abstract}

Keywords: foreign languages, motivation, master education.

\section{Introduction}

The present research is devoted to find new methods of increasing motivation to study foreign languages in the sphere of engineering education for professional (specific) purposes. Every teacher of foreign languages faces with the problem of motivation to study the subject "Foreign language" or "Foreign language in the professional sphere" and makes attempts to solve it.

The author agrees with M. Pace, who writes that: "Most businesses today need workers, who can speak different languages, not only for communication purposes, but also to understand the different cultural realities and needs that exist around the globe. Mastery of foreign languages has become, in today's world, a vital instrument that enables workers to considerably improve their career prospects, since multilingualism is considered to be one of the key elements for a modern Europe. In today's world, knowing how to use a language in specific circumstances and purposes gives people a very strong bargaining power, especially in the labour world" [1].

So, it is quiet obvious that knowing foreign language is a $21^{\text {st }}$ century skill of every specialist of any professional sphere. That is why the problem of motivation, in particular motivation to study foreign languages, is of great scientific interest among many scientists [2-4].

Motivation has long been identified as one of the main factors affecting the English language learning [5].

Dita Gálová [6] believes that "globalization of the world economy requires professionals and specialists in various areas to communicate effectively in foreign languages. The success is conditional on their ability to manage language and cultural barriers, i.e. on the language skills and competences with respect to their professional areas".

Parsons, Hinson and Brown determine motivation [7] as an important component or factor in the learning process. Learning and motivation have the same importance in order to achieve something. Learning makes students gain new knowledge and skills and their motivation pushes them or encourages them to go through the learning process successfully [8].

Studying the problem of motivation the author referred to the definition of "inner motivation to study". V. E. Milman wrote that: "cognitive and direct interests of students in realization of the process and achievement of educational results are inner motives of studying" [9]. According to this explanation it was supposed that teachers should pay more attention to the formation of inner motivation of their students while conducting lessons of the foreign language. Revealing the ideas of inner motivation to study foreign languages, the author decided to suggest students to think about 
forms of lessons or other language activities, which can really motivate them to study foreign languages.

\section{Materials and methods}

The ways how to solve the problem of motivation to study foreign languages for Master students determined the scientific method of the research. As the author follows the student-centered approach, it was defined that it was very important to get information from students, to find out what solution they could suggest [10]. That is why the main scientific method of this research is questionnaire. Such method allows to see the students' point of view on the problem and to find possible solution of this problem by asking them different questions. To state, if there were any positive changes in the students' answers, the author decided to organize two questionnaires.

The aim of the first questionnaire was to determine, if the students of engineering education had or did not have a wish to take part in the foreign language activities organized by the university, and also to find out, if they needed the knowledge of foreign languages for the professional purposes. The questions of the first questionnaire were the following.

1. What content (educational materials) does the subject "Foreign language in the professional sphere" should have?

2. Do you want to study foreign language at the Master degree programme? Why?

3. Do you want to continue studying foreign language after graduation?

4. Would you take part in the foreign language contest? What forms of this contest can you recommend?

The questionnaire contains only these questions, because it was important to find out, whether the Master students want to improve their English level taking part in the language contest. The questionnaire survey involved 214 respondents. Having got answers of the questionnaire, the author realized the necessity of organizing a foreign language contest, which will help increase student motivation to study foreign languages. So, the tasks of the foreign language contest were worked out on the basis of the answers of the students. First, all tasks were connected with the professional sphere of the students - engineering sphere; second, these tasks also showed that professional sphere includes not only special engineering words, but it has a correlation with basics of the business world, where you have to use foreign language at negotiations, while telephoning with your business partner, working in a team in a joint or international company, taking part in job interviews, writing CV, cover letter or professional biography. So, the author tried to motivate the students showing them that there were many opportunities to use foreign languages in the professional engineering sphere; that is why it was important to persuade the students to continue studying this subject at the Master degree programme.

The purpose of the second questionnaire was to find out, if there were any positive changes in the motivation to study foreign languages. Participants of the organized foreign language contest were applicants for the Master degree from different universities of the Russian Federation representing the following engineering education: chemical engineering, civil engineering, mechanical engineering, electrical engineering.

\section{Results and discussion}

Having conducted the first questionnaire and analyzed the answers of the Master students of the engineering education, the author got the following results:

1. Answering the first question of the questionnaire, $73 \%$ of students wrote they needed knowledge, which would be of great help for them in their professional life, for example, educational material from business English (how to fulfil documents in English, how to write business letters, to be a successful speaker at presentations or during negotiations).

2. A positive answer at the second question "Do you want to study foreign language at the Master degree programme" was given by $61 \%$ of students, explaining that they did not have foreign language classes after the second course of the bachelor programme and they understood that they would need foreign languages for their profession, or for many, who have already found a working place, knowing foreign language at medium or high level is required by the employer. 
3. $72 \%$ of students wrote "yes" for the third question - "Do you want to continue studying foreign language after graduation". In spite the fact that $39 \%$ considered not to use foreign languages for specific purposes, they explained that they would need use foreign languages for personal purposes, for example, while travelling.

4. $49 \%$ of students showed their willingness to take part in the foreign language contest, because, as they explained, the contest tasks are supposed always to be very creative and exciting. So it enables students to show their creativity and unordinary way of thinking by solving problems using also means of foreign languages. As for the possible forms of the contest the students suggested: Olympiad, game activities on the example of "What? Where? When?", "Brain Ring".

According to these answers the author worked out the tasks of the contest. It was decided to organize the I All-Russian contest (Olympiad) for Master students of non-linguistic education. As for the tasks the organizing committee and the author were discussing what tasks would be not only interesting for the students, but also useful to meet their professional purposes.

The answers on the first question of the questionnaire helped determine the content of the contest tasks. So, the tasks were the following: 1) write a cover letter to the employer about your strong motivation to work in his/her company; 2) create your own mind map with the topic "My future job in the international company"; 3) lexical and grammar task in professional sphere "At Job Interview write 3 questions and possible successful and unsuccessful answers, which are usually given during job interview. Explain why these variants are good or bad"; 4) creative task "Translate a poem using art means of your native language". On the basis of the students' answers the tasks of the contest aimed, on the one hand, to test their knowledge regarding information from the business sphere, and on the other hand, to let the students demonstrate their creative way of thinking.

Then to see the changes in the students' answers it was decided to organize the second questionnaire, containing the same questions. Fig. 1 shows positive dynamics in the changing of motivation to study foreign languages.

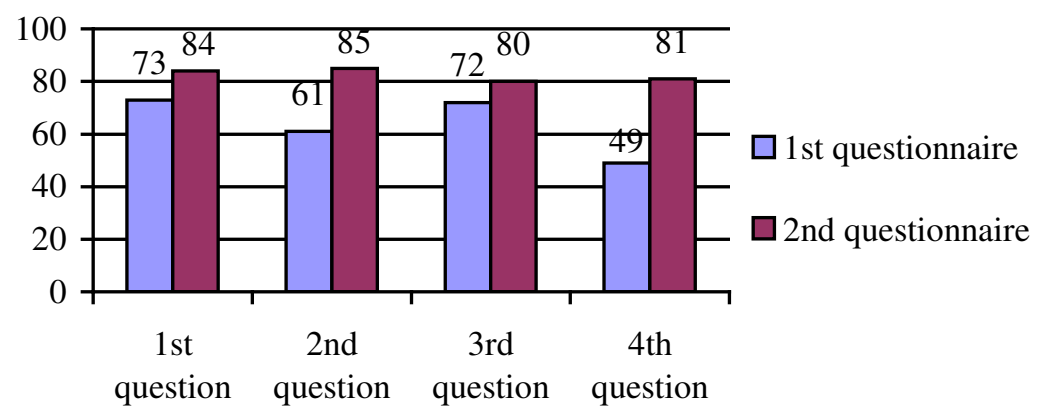

Fig. 1. Dynamics of changing motivation to study foreign languages, \%

Comparing the results of the first and the second questionnaires, the author underlined positive changes in the motivation to study foreign languages. The first explanation of these positive changes is the form of the foreign language contest suggested by the students. It should be noted that the biggest growth is seen in the changes of the answers to the $4^{\text {th }}$ question, because having conducted this contest, the students, who did not take part in it, had an opportunity to see the tasks (the tasks were free online in the social net) and while in the second questionnaire they explained their willingness to be a participant next year at this contest or another one, because the tasks were not only exciting, but also very useful for specific purposes.

Besides, all students wrote that they understood the value of having a good level of knowledge of foreign language, which would allow them to take part not only in the language activities organized in the university, but also to be a part of international business and activities held in their firms, companies, plants, etc.

The second explanation is that educational material was personal-oriented; that is why the growth of indexes for the $1^{\text {st }}, 2^{\text {nd }}$ and $3^{\text {rd }}$ questions is noted. The author believes that the key to success in the matter of increasing motivation to study foreign languages for the Master students of engineering education was the reference to their interests regarding their profession. So, this is the reason of positive changes of indexes, because the students were shown an opportunity to take into account their 
interests for specific purposes and to combine these interests with the educational process of studying foreign languages, using not only classical forms of conducting lessons, but also new forms to increase the motivation to study.

\section{Conclusions}

1. The conducted research showed opportunities how to solve the problem of increasing motivation to study foreign languages on the example of organization of the I All-Russian contest (Olympiad) for Master students of non-linguistic education. So, our method is supposed to be one of additional, but efficient methods of students' motivation improvement to study foreign languages.

2. The experience of holding such contest was successful, because the inner motivation of students was referred to, so it means that they wanted to take part in this contest, they were highly motivated to be involved in this activity. From pedagogical point of view the tasks of the foreign language contest and the contest itself were of great interest to students and the theme of the tasks was student-centered. So, it means that the students took part in this contest with interest and they explained later during the second questionnaire that it was exciting for them to do the tasks and they also got new information thanks to foreign language.

3. The required results allow to speak about feasibility to work out, organize and conduct similar contests and activities for students to increase their motivation to study foreign languages and the positive result has been achieved and proved in this research.

\section{References}

[1] Pace M. The Teaching of Foreign Languages for Specific Purposes: The Way Forward. In The Educator. A Journal of Educational Matters. Issue No. 1/2013, pp. 15-22. Valletta : Malta Union of Teachers [online]. Available from: http://mut.org.mt /wp-content/uploads/2015/08/TheEducator-Issue-No-1-2013.pdf.

[2] Батунова И.В., Березина К.И. Формирование мотивации студентов при изучении иностранного языка в неязыковых вузах (Formation of student motivation at learning of foreign language in non-linguistic universities). International scientific and investigation journal, № 05 (59), Part 2, May, 2017, pp. 10-12. (In Russian).

[3] Зимняя И.А. Ключевые компетенции - новая парадигма результата современного образования (Key Competences - New Paradigm of Results in Modern Education). Internet journal "Eidos", May 5, 2006. Available at: http://www.eidos.ru/journal/2006/0505.htm (In Russian).

[4] Швалова Г. В. Формирование мотивации студентов технического вуза при изучении профессионального иностранного языка (Motivation formation of technical institute students in the studying of professional foreign language). Periodic scientific and methodological e-journal “Koncept”, 2012. №11 (15). Available at: http://cyberleninka.ru/article/n/formirovanie-motivatsiistudentov-tehnicheskogo-vuza-pri-izuchenii-professionalnogo-inostrannogo-yazyka (In Russian).

[5] Gardner R.C. Social psychology and second language learning: The role of attitudes and motivation. London : Edward Arnold Publishers, 1985.

[6] Gálová D. ed. Languages for Specific Purposes. Searching for Common Solutions. Cambridge: Cambridge Scholars Publishing, 2007.

[7] Parsons R., Hinson S., Brown D. Educational psychology : practitioner - researcher models of teaching. University of Virginia: Wadsworth Thomson Learning, 2001.

[8] Wimolmas R. A Survey Study of Motivation in English Language Learning of First Year Undergraduate Students at Sirindhorn International Institute of Technology (SIIT), Thammasat University, 2013. [online] Available from: http://www. litu.tu.ac.th /journal /FLLTCP/Proceeding/904.pdf

[9] Мильман Е.В. Внутренняя и внешняя мотивация учебной деятельности (Inner and internal motivation of learning activivty). Matters of Psychology, 5. 1987. pp. 129-138. Available at: http://www.voppsy.ru/issues/1987/875/875129.htm (In Russian).

[10] Gou B. Contemporary teaching strategies in general chemistry. The China Papers, July 2003, pp. 39-41. 